\title{
ОСОБЕННОСТИ ПОЛИМОРФИЗМА БИОЛОГИЧЕСКИ АКТИВНЫХ ПРОИЗВОДНЫХ ИМИДАЗОЛА
}

\author{
И.Н. Карасева, М.О. Карасев, С.В. Курбатова \\ Химический факультет, Самарский национальный исследовательский университет \\ им. академика С.П. Королева, 443011, Россия, г. Самара, Академика Павлова, 1.
}

DOI: 10.19163/MedChemRussia2021-2021-486

E-mail: curbatsv@gmail.com

Различия в физико-химических характеристиках разных полиморфных модификаций, как известно, могут оказывать влияние на физиологически важные свойства этих соединений [1]. Практически установленным является влияние полиморфизма на растворимость, проницаемость биологических барьеров, скорость поступления в организм и адресную доставку, изменение токсичности и т.п., что может привести к фармацевтической и, как следствие, фармакокинетической и терапевтической неэквивалентности препаратов в твердой лекарственной форме, и, таким образом, к различиям в биодоступности лекарственных средств. Нами с помощью метода невалентных взаимодействий, базирующегося на использовании характеристик молекулярных полиэдров Вороного-Дирихле, осуществлен кристаллохимический анализ полиморфных модификаций биологически активных производных имидазола с брутто-формулой $\mathrm{C}_{a} \mathrm{H}_{b} \mathrm{~N}_{c}$. Показано, что различные полиморфные модификации подобных структур различаются в первую очередь количеством невалентных внутримолекулярных контактов. Увеличение числа возможных конформаций, которые могут быть реализованы за счет вращения заместителей по б-связям, приводит к возрастанию числа внутримолекулярных невалентных контактов, лежащих в пределах от 20 для незамещенного имидазола до 176 для одного из полиморфов 2,4,5-трифенилимидазола. Установлено, что среди полиморфов фенилимидазолов ярко выражено явление конформационного полиморфизма, обусловленного свободным вращением фенильных групп относительно имидазольного фрагмента по б-связям С-С. Из полученных нами данных следует также, что каждой полиморфной модификации производных имидазола соответствует уникальное сочетание типов невалентных межмолекулярных и внутримолекулярных взаимодействий.

Работа выполнена при поддержке Министерства образования

и науки Российской Федерации в рамках государственного задания по гранту № FSSS-2020-0016.

\section{Литература}

[1] И.Г. Смирнова, Г.Н. Гильдеева, В.В.Чистяков, Вестн. Моск.ун-та. Сер.2. Химия. 2012, Т.53, №4. С. $234-240$. 